\title{
Effects of Training Materials and Methods on the Performance of Employee of the Commission for Land in Zanzibar
}

\author{
Raya Akida Haji ${ }^{1}$, Salam Yussuf ${ }^{2}$, Abdalla Ussi Hamad ${ }^{3}$ \\ ${ }^{1}$ Department of Public Administration, Faculty of Arts and Social Science, Zanzibar University, Zanzibar, Tanzania \\ ${ }^{2}$ Departmet of Accounting and Finance, Faculty of Business Administration, Zanzibar University, Zanzibar, Tanzania \\ ${ }^{3}$ Department of Economic, Faculty of Arts and Social Science, Zanzibar University, Zanzibar, Tanzania
}

Email address:

rayaakida87@gmail.com (R. A. Haji), abdalla.hamad@zanvarsity.ac.tz (A. U. Hamad)

\section{To cite this article:}

Raya Akida Haji, Salam Yussuf, Abdalla Ussi Hamad. Effects of Training Materials and Methods on the Performance of Employee of the Commission for Land in Zanzibar. Journal of Human Resource Management. Vol. 9, No. 2, 2021, pp. 43-49.

doi: $10.11648 /$ j.jhrm.20210902.13

Received: May 17, 2021; Accepted: June 7, 2021; Published: June 21, 2021

\begin{abstract}
The main aim of this study is to examine the effects of training materials and methods on the performance of employee of the commission for land in Zanzibar. The researcher has mainly employed quantitative research approach with appropriate method of analysis for this study. Both purposive and simple random sampling designs were used to select sample size for this study. The sample size for this study consists of 91 respondents and survey questionnaire was used as data collection instrument. To achieve a credible study a multiple regression was used to analyse the collected data from relevant respondents. The study has revealed that two predictors (training material and training method) had a significant effect or impact on the outcome variable (employee's performance). In other words, the results of predictor variables are; training material $(\beta=0.246, \mathrm{t}=2.241, \mathrm{p}<0.05)$, training method $(\beta=0.248, \mathrm{t}=2.313, \mathrm{p}<0.05)$. Basically, the effect of training material and training method on employees' performance COLA in Zanzibar was in a positive direction. The study conclude that the COLA should plan and implement these two indicators (training material and training methods) so as to run a cycle of increasing skills in employees in order to increase performance.
\end{abstract}

Keywords: Training Material, Training Methods, Employee Performance, Standard Multiple Regression

\section{Introduction}

The employees' Management is the hardiest task in any organisation. It involves the management of job responsibilities and job creation in order to increase the work performance. More specifically, the employees' involvement, sincerity, creativity and dedication to the job that management expects do not seem to be the result of financial incentives as was believed earlier, it is observed that despite the adequate incentives, motivation to better performance still lacking [1], and [2]. As many of today's organisations like schools, corporations, and social institutions continue to struggle to remain competitive and profitable, it has become necessary for managers and administrators to recognise and understand the factors that influence employee's performance [1].

In this World of Globalization, employer have focused much in the training of their employee largely because they want to gain competitive advantages through employee performance as explained by [3] that human resources are valuable and a source of competitive advantages. Improved capabilities, knowledge and skills of the talented workforce have been proved to be a major source of competitive advantage in a global market [4]. Training is a necessity in the workplace. Without it, employees don't have a firm grasp on their responsibilities or duties. Employee training refers to programs that provide workers with information, new skills, or professional development opportunities. The companies aimed at gaining the competitive advantage realized the importance of training in improving the employees' performance.

Past researches provides the evidence regarding the positive affect of training programs on both employee and 
organizational performance. On one hand previous work in the field proved that effective training programs leads to superior return on investment while the other researches mentioned the positive role of training in attaining the supreme levels of employee retention [5]. Generally, an organization equipped with well-trained and developed employees is able to avoid wasteful spending of resources, increases its productivity and improves performance. In other words, the working environment attracts staffs and motivates its performance.

The survival of any organization in the competitive society lies in its ability to train its human resource to be creative, innovative and inventive. Training is a technique for improving employees' performance and it is expected to yield positive changes in knowledge, skills and attitudes. It is worth noting that an employee is a blood stream of organization, thus training improves skills and quality of his work. When employees recognize that organization shows invaluable interest in them through offering training programs, they will in turn apply their best efforts to achieve organizational goals, and show high performance on job.

It is essentially important to develop a positive and constructive organisational climate that promotes and encourages staff motivation, which ultimately increases employee's performance. Organisational managers should therefore understand the associations between organisational climate, employee's motivation and job performance in order to use their experience in devising some changes that will prompt their employees to do excellent work and thus improve job performance [6].

During the period of 1989, the Revolution Government of Zanzibar (RGoZ) provided a legislation to establish a new body which was known as the Commission for Lands and Environment. The main purpose of establishing this body is to have one government organ to deal exclusively with land administration and do away with a confusing situation where more than one organ was responsible for land issues. The Commission was semi-autonomous with its own decision making mechanism. This was a major institutional development in the post revolution period. The Commission was empowered to administer all land within Zanzibar territory, both in urban and rural areas. It brought together different professions and people who were dealing with land issues. Along with them, they brought equipment and transport facilities to the benefit of the Commission [7].

Several series of acts have been introduced since the establishment of new body of Commission for Lands and Environment. These acts are; The Land Adjudication Act (1989), The Registered Land Act (1989), The Land Surveyor's Act (1989), Land Tenure Act (1992), Land Transfer Act (1993) and The Land Tribunal Act (1994) [7]. In order to comply with these acts, the employees were supposed to get training on the new acts so as to work effectively.

\section{Problem Statement}

Training is a systematic process to enhance employees' skills, knowledge and competency necessary to perform their duties effectively within the organization. Despite the fact that employees training is said to have the significant impacts on the employees' performance, it is unfortunate that many private and even some public organizations seems not to be aware of its importance [8]. This situation may, in one way or another, lead to high job turnover and poor organizational performance and profitability potentials.

Moreover, there have been a lot of empirical studies that are in support of the fact that performance can be improved when employees are well and frequently trained. The studies of $[9,10]$ and $[11]$ indicated a positive link between training and employees' performance. It was argued in this view that training brings benefits and positively enhances employees' competencies.

However, despite the existence of voluminous literatures on the importance of training to employees' performance, there are very limited literatures conducted on public organizations in Zanzibar which examined and assesses the impacts or relationship between the employees' training and employees' performance. In this regard, this study intends to complement the existing knowledge and critically examine the effect of training material and methods on performance of employee especially to the Public Sector with the special focus to Commission for Land (COLA).

\section{Theoretical Literature Review}

Goal Theory: Goal theory, as developed by [12] and highlights four mechanisms that connect goals to performance outcomes: 1) they direct attention to priorities; 2) they stimulate the process of Performance Management effort; 3) they challenge people to bring their knowledge and skills to bear to increase their chances of success; and 4) the more challenging the goal, the more people will draw on their full repertoire of skills. This theory underpins the emphasis in performance management on setting and agreeing objectives against which performance can be measured and managed. As adapted to this study people are more likely to achieve difficult yet attainable goals than they are to achieve less difficult goals. In addition, the theory proposed establishes an intimate link between goal setting and employees training.

Resource-Based View (RBV) Theory: According to [13] introduces the concept of the resource-based view (RBV). The resource-based view (RBV) is based on the idea that the effective and efficient application of all useful resources that company can muster helps determine its advantage. The origins of the resource-based view can be traced back to earlier research. Retrospectively, elements can be found in works [14] where emphasis is put on the importance of resources and its implications for firm performance. Major concern in RBV is focused on the ability of the firm to maintain a combination of resources that cannot be possessed or built up in a similar manner by competitors. 


\section{Empirical Literature Review}

Several studies were reviewed which related to nature of this study. The followings are some of them.

According to [15] measures the perception of employees on the impact of training to the employee performance: evidence from two Chinese manufacturing firms. Survey questionnaires were used for data collection from the sample size of 348 supervisor-subordinate dyads from two Chinese manufacturing firms. Process macro tool (Hayes) was used to test the mediating role of work engagement and the moderating role of HRM strength in the training-performance relationship. The findings of the paper revealed that, work engagement mediates the relationship between training and in-role task performance, while the relationships between work engagement and both task performance and organizational citizenship behavior are moderated by HRM strength.

Also, the study of [16] examines the effects of training on employee performance - a study on Banking Sector, Tangail Bangladesh. Data for the paper has been collected through primary source that are from questionnaires surveys. A survey of 150 employees via self-administrated questionnaire with the help of stratified sampling technique is conducted with the response rate of almost $75 \%$. Descriptive analysis, T-test, Correlation, and Regression analysis were used to analyse the data. On the role of training the study showed that general training enhances employee engagement, employee motivation and job satisfaction. The Hypotheses showed that all these had significant effects on Employee Performance. That means, this research found that strong relationship exists between employee training and employees' performance. The results reveal that the more the employee gets training, the more efficient their level of performance would be.

Furhermore, [17] conducted study on the training employee engagement and employee performance: Evidence from Uganda's health sector. The nature of this study is cross sectional and correlational. They distribute a questionnaires to 150 respondents from four Catholic founded hospitals that is Kamuli Mission Hospital, Buluba Mission Hospital, St. Benedict Mission Hospital and Budini Mission Hospital. The creditable result from regression analysis results indicate that training and employee engagement significantly predict employee performance by $44.7 \%$ and employee engagement was found to be a major predictor of employee performance as compared to training. In addition to that, the correlation analysis results indicate that there is a significant positive relationship between training and employee performance. Correlation analysis results further indicate that there is a significant positive relationship between employee engagement and employee performance. A partial mediation effect of employee engagement in the relationship between training and employee performance was also established.

Moreover, the study on the impact of training on employee performance in Private Insurance sector is conducted in India. The result obtained shown that training imparted to employees of Private Insurance company in Coimbatore improve the level of their performance considering other factors such as education level and work experience [18]. The performance is seen in the level of productivity after training. Effective training programs aimed at improving the employees' performance can be given through different methods such as coaching, cooperation and participation by the subordinates. This enables employees to actively participate on the job and perform better. Additionally, training programs enable employees to deal with the customer in an effective manner and respond to their complaints in timely manner. Meanwhile, employees' training helps an organization to make best use of their human resources; therefore, enhance their abilities and competencies that are needed at the workplace.

Notwithstanding, [19] studied the effectiveness of employee training programs on performance of employees. This was an empirical study of private sector companies in Saudi Arabia. The study adopted an analytical research design. Random sampling technique, used due to large number of respondents; a questionnaire used for data collection from the respondents. Correlation coefficient used to interpret results and one way ANOVA used to test hypothesis. The study findings show that there is a positive relationship between training programs and employees performances in private sector in Saudi Arabia. Most of the respondents agreed that training improves skills and knowledge they possess and helps them to solve problems. The ability to solve problems is a catalyst for employee retention. The study was however limited to only private companies.

The authors assessed the importance of training and development in Public Water Utilities in Tanzania [20]. The study find out that Training and Development is statistically positively correlated on the performance of public water utilities in Tanzania. The study recommend the implementation of the training need assessment and budget for implementation of training and development programme as they hold positive influence on the employee performance and organization.

Throgh the impact of training and development on employee performance and effectiveness were examine focusing on Five District Administration office, Bole sub city, Addis Ababa, Ethiopia [21]. The study made use of questionnaire. A questionnaire was administered to the various groups of employees of the organizations. The outcome of the study reveals that training and development has positive correlation and vital relationship with employee performance and effectiveness.

The investigations of the role of employees training in the organization performance were conducted at Tanzania Revenue Authority, Ilala Tax Region Dar es Salaam by [22]. The result reveals that, training is an important strategic tool for improving employee performance. Therefore researcher suggest organization should keep on increasing training budget every year believing that they will have competitive staff. 
Finally, the author [23] conducted a study to investigate the impact of entrepreneurial training on micro and small enterprises performance in Ilala District Dar es Salaam, Tanzania. The study used a combination of exploratory and experiential research design. Exploratory research design was to make the researcher understand entrepreneurship training using a case study approach and experimental or casual research design was to enable the researcher obtain relationship between variables that is training and performance of MSEs. The process for selecting sample size is not scientific. Data collected by use of interviews, observation, questionnaires and document reviews. Quantitative data analyzed by use of SPSS and qualitative data analyzed by pattern matching technique: information arranged in groups of similar meaning. The findings show that there is a positive relationship and between entrepreneurship training and performance of SMEs in Ilala Dar Es Salaam.

\section{Methodology}

Research Design: For purpose of this study a quantitative research design was used in this study in order to explore a phenomenon, explain and interpret the data widely and easily. The quantitative research design was used in this study to quantitatively show the magnitude of the effect of employee training material on employee's performance at COLA in Zanzibar.

Study Population: The target populations for this study comprise a permanent staffs of the Commission for Land (COLA). They are about 219 permanent staffs at COLA from different departments and units and they are of different level of seniority and education.

Sampling techniques and sample size: Simple random sampling designs were used to select a sample of 91 respondents and considered as appropriate for a study of this nature.

Data Collection Methods: The primary data were collected using questionnaires survey. The self-administered questionnaire was used because it enables the researcher to collect data from relatively large sample, limited the biasness from the interviewer and protected the privacy of respondents. The statement on which participants' response is solicited is based on a five-point Likert-type rating scale. It requires the respondents to indicate how much or to what extent they agree or disagree with a given statement on each construct. Following this type of rating scale, the options range is from lowest to highest responses - one (1) to seven (5). This options are strongly disagreeing $(\mathrm{SD})=1$, disagree (D) $=2$, neutral $(\mathrm{N})=3$, agree $(\mathrm{A})=4$, strongly agree (SA) $=5$. There are 9 items in the questionnaire survey and each variable is tested by separate item. The questionnaire survey is attached

Reliability of Instrument: The reliability test was conducted using Cronbach's alpha coefficient with value of 0.70 and above considered acceptable and meet standard for the research instrument to be employed for analysis (Palant,
2007). The following table below shows the reliability test of the 14 variables of this study.

Table 1. Reliability Statistics.

\begin{tabular}{lll}
\hline $\begin{array}{l}\text { Cronbach's } \\
\text { Alpha }\end{array}$ & $\begin{array}{l}\text { Cronbach's Alpha Based on } \\
\text { Standardized Items }\end{array}$ & N of Items \\
\hline .766 & .775 & 14 \\
\hline
\end{tabular}

Source: Researcher Computation, 2021

Data Analysis: Since the study is quantitative in nature; therefore, the information gathered was analyzed quantitatively. The standard multiple regression, was used using Statistical Package for Social Sciences (SPSS) (version 23)

\section{Study Findings}

\subsection{Demographic of the Respondents}

Table 2. Demographic Data of the Respondents.

\begin{tabular}{llll}
\hline Variable & Category & Frequency & Percentage (\%) \\
\hline \multirow{2}{*}{ Gender } & Male & 72 & 79.5 \\
& Female & 19 & 20.5 \\
& $20-30$ & 23 & 25.2 \\
Age & $31-40$ & 44 & 48.4 \\
& $41-50$ & 18 & 19.8 \\
& 51 and above & 6 & 6.6 \\
Education & Certificate & 7 & 7.7 \\
& Diploma & 14 & 15.4 \\
& Degree & 58 & 63.7 \\
\multirow{2}{*}{ Working } & Master and above & 12 & 13.2 \\
experiences & 1to 5 years & 15 & 15.4 \\
& 6 to 10 years & 57 & 62.6 \\
& 11 years and above & 20 & 22.0 \\
\hline
\end{tabular}

Source: Field data, 2021

By gender, table 2 above shows that out of the total respondents investigated for this study, overwhelming majority (79.5 per cent) of them were males whereas about 20.5 per cent were found to be females. In a Zanzibar social conditions the positions are normally headed by the males and head was the unit for data collection, from the given sample very few units are headed by the females. Based on the classification of the age range, 25.2 percent of the respondents are with the age between 20 to 30 years. At this age, people are working very hard in order to cope with life as it is rare to get position in organization. Moreover, 68.2 percent of the respondents are between the ages of 31 to 40 years and 1 to 50 years, and are more than half of the total respondents. Furthermore, there is another age in this study that are also examined, the respondents with 51 years and above comprise only 6.6 percent of the total respondents. At this stage, it is likely that respondents are not much considered to be given training for work performance; as often, they would not be very much involved in organizational activities

Furthermore, Table 2 shows that about 8 per cent of the respondents were educated up to certificate and relatively lesser number of them, 15.4 per cent was educated up to diploma level. The numbers of respondents attaining higher 
education were very high. More than half (63.7 per cent) of the respondents were educated up to degree level. A considerable number of respondents were having enough knowledge related to important of training activities and more than 13 per cent of them were master and above.

Finally, the summarized results from Table 2 revealed that, 14 respondents equal to $(15.4 \%)$ had experience of 1 to 5 year, 57 respondents equal to $(62.6 \%)$ had experience of 6 to 10 year, and 20 respondents equal to $(22 \%)$ had experience of 11 years and above. Therefore, the study clearly indicated that, a large numbers of respondents working at COLA in Zanzibar had experience of 6 to 10 years.

\subsection{Standard Multiple Regression}

In Standard multiple regression all the independent (or predictor) variables are entered into the equation simultaneously. Each independent variable is evaluated in terms of its predictive power, over and above that offered by all the other independent variables [24]. In the same line, standard multiple regression is the most commonly used technique since it informs the researcher how much unique variance in the outcome variable each of the predictor variable explained.
The results of standard multiple regression as displayed in Table 3 below indicated that the independent variables training method, training material accounted for $39 \%$ of the variability in employees performance commission for land (COLA) in Zanzibar $\left(\mathrm{R}^{2}=0.390\right)$. The adjusted $\mathrm{R}$ square value was 0.352 . Therefore, these findings substantiate that only $39 \%$ of variability in employee's performance could be explained by factors like training method, training material. The remaining $61 \%$ of variability depends on other unexplained factors.

Table 3. Model Summary ${ }^{b}$.

\begin{tabular}{lllll}
\hline Model & $\mathbf{R}$ & $\begin{array}{l}\mathbf{R} \\
\text { Square }\end{array}$ & $\begin{array}{l}\text { Adjusted R } \\
\text { Square }\end{array}$ & $\begin{array}{l}\text { Std. Error of } \\
\text { the Estimate }\end{array}$ \\
\hline 1 & $.390^{\mathrm{a}}$ & .352 & .390 & .43378 \\
\hline
\end{tabular}

a. Predictors: (Constant), Training Method, Training Material

b. Dependent Variable: Employee Performance

Furthermore, the following table 4 below displays the coefficients' columns for the standard multiple regressions conducted.

Table 4. Coefficients ${ }^{a}$.

\begin{tabular}{llllll}
\hline \multirow{2}{*}{ Model } & & \multicolumn{2}{c}{ Unstandardized Coefficients } & Standardized Coefficients & Sig. \\
\cline { 3 - 5 } & & B & Std. Error & Beta & \\
\hline \multirow{2}{*}{1} & (Constant) & 2.603 & .530 & & .000 \\
& Training Material & .214 & .095 & .246 & 2.915 \\
& Training Method & .211 & .091 & .248 & .028 \\
\hline
\end{tabular}

a. Dependent Variable: Employee Performance

The table 4 above shows the coefficients for training method and training material on Employee Performance at the 0.05 level of confidence.

The study has revealed that two predictors (training material and training method) had a significant effect or impact on the outcome variable (employee's performance). In other words, the results of predictor variables as seen in Table 4 above are as follow:- training material $(\beta=0.246, \mathrm{t}=2.241, \mathrm{p}<0.05)$, training method $(\beta=0.248, \mathrm{t}=2.313, \mathrm{p}<0.05)$.

Basically, the effect of training material and training method on employees' performance COLA in Zanzibar was in a positive direction. This situation indicates that the increase of scores in these predictor variables results in the increase of scores in the outcome variable [24]. This situation indicate that employees of COLA are highly satisfied with material used in training and the methods used to deliver the material of the training which finally tend to perform their job better. Therefore, these findings provide the opportunities for the high management of Commission for Land (COLA) in Zanzibar to improve their employees' job performance by adopting high level of Islamic work ethic culture in the work settings as well as creating different means of satisfying employees in terms of pay, supervision, but also facilitating friendly environment in which workers ultimately could help one another.

As previously stated, that the findings of the training material and training method on employees performance available. For example, these findings are corresponding with the study of [15] which measures the perceptions of the employee on the impact of training to their performance [15]. The findings shows that, work engagement mediates the relationship between training and in-role task performance, while the relationships between work engagement and both task performance and organizational citizenship behavior are moderated by HRM strength.

In addition, [16] examine the effects of training on employee performance - a study on Banking Sector, Tangail Bangladesh. The results reveal that the more the employee gets training, the more efficient their level of performance would be. Also, the result was supported by [17] who conducted a study on the training, employee engagement and employee performance: Evidence from Uganda's health sector. The result indicates that training and employee engagement significantly predict employee performance by $44.7 \%$. Moreover, the results for this study is consistence with the study of [18] which found that training imparted to employees improve the level of their performance considering other factors such as education level and work experience. Meanwhile, employees' training helps an organization to make best use of their human resources; therefore, enhance their abilities and competencies that are needed at the workplace. 


\section{Conclusions}

The conclusion of the study were drown from the main findings of this study which aimed at examines the effect of training methods and training material on performance of employee of the Commission for Land in Zanzibar. Therefore, the study concluded that, the training material, and training methods are highly effect the employees performance which should be planned and implemented by COLA so as to run a cycle of increasing skills in employees in order to increase performance, which in turn increase their collective performance and thus further result on Commission to growth its functions.

\section{Recommendations}

Based on the findings and conclusions, the study recommended that the management of COLA should create more opportunities for training and development of their employee since it has been proven that there is a direct link between training and development with performance. Therefore employees should be encouraged to go for training and development program (in service training). This will brighten up their ideas and will enable them to know more about the recent changes in technologies.

Furthermore, the Commission should establish the training objective in accordance with the Commission goal. This will ensure that the needed training and development programmes are identified and implemented. It will help in reducing the impression of some employees that these programmes are a waste of time and therefore take it serious.

\section{References}

[1] Riggle, R. J. (2007). The impact of organizational climate variables of perceived organizational support, workplace isolation, and ethical climate on salesperson psychological and behavioral work outcomes. PhD Thesis, University of South Florida, USA.

[2] Erhart, M. G., Schneider, B., \& Macey, W. H. (2014). Organizational Climate and Culture: An Introduction to Theory, Research and Practice (1st ed.). Routledge, 711 Third Avenue, NY, USA.

[3] Armstrong, M., \& Baron, A. (2002). Strategic HRM: The key to improved business performance. London: Chartered Institute of Personnel and Development.

[4] Krause, J. (2006). Organizing for successful change management : A McKinsey Global Survey. London UK.

[5] Colarelli, S. M., \& Montei, M. S. (1996). Some contextual influences on training utilization. Journal of Applied Behavioral Science, 32 (3), 306-322.

[6] Suliman, A., \& Al-Harethi, B. (2013). Perceived work climate and employee performance in public security organizations in the UAE. Transforming Government: People, Process and Policy, 7 (3), 410-424. http://doi.org/10.1108/TG-03-20120001
[7] Abdulla, S. R. (2006). Institutional Developments in Land Administration in Zanzibar. Zanzibar

[8] Mamun, C. A. Al, \& Hasan, M. N. (2017). Factors affecting employee turnover and sound retention strategies in business organization: A conceptual view. Problems and Perspectives in Management, 15 (1), 63-71.

[9] Falola, H. O., Osibanjo, A. O., \& Ojo, S. I. (2014). Effectiveness of Training and Development on Employees Performance and Organisation Competitiveness in the Nigerian Banking Industry. Bulletin of the Transilvania University of Brasov Series V: Economic Sciences, 7 (56), 161-170.

[10] Franklin, D. K., Cowden, R., \& Karodia, A. M. (2014). The impact of training and Developemnt on Job Performance. Singapolean Journal of Business Economics, and Management Studies, 3 (3), 1-34.

[11] Athar, R., \& Shah, F. M. (2015). Impact of Training on Employee Performance (Banking Sector Karachi). IOSR Journal of Business and ManagementVer. I, 17 (11), 23197668 .

[12] Latham, G. P., \& Locke, E. A. (1979). Goal setting-A motivational technique that works. Organizational Dynamics, 8 (2), 68-80. http://doi.org/https://doi.org/10.1016/00902616(79)90032-9

[13] Barney, J. B. (1991), "Firm resources and sustained competitive advantage", Journal of Management, 17 (1), pp. 99-12.

[14] Wernerfelt, B. (1984). A resource-based view of the firm. Strategic Management Journal, CINCO (2), 1-12.

[15] Guan, X., \& Frenkel, S. (2019). How perceptions of training impact employee performance: Evidence from two Chinese manufacturing firms. Personnel Review, 48 (1), 163-183.

[16] Afroz, N. N. (2018). Effects of Training on Employee Performance: A Study on Banking Sector, Tangail Bangladesh. Global Journal of Economic and Business, 4 (1), 111-124. http://doi.org/10.12816/0048158

[17] Sendawula, K., Nakyejwe Kimuli, S., Bananuka, J., \& Najjemba Muganga, G. (2018). Training, employee engagement and employee performance: Evidence from Uganda's health sector. Cogent Business and Management, 5 (1), 1-12.

[18] Anitha, R., \& Kumar, M. A. (2016). A Study on the Impact of Training on Employee Performance in Private Insurance Sector, Coimbatore District. International Journal of Management Research \& Review, 6 (8), 1079-1089.

[19] Alshuwairekh, K. N. (2016). The Effectiveness of the Training Programs on Employees Performance: An Empirical Study at Private Sector Companies in Saudi Arabia. International Journal of Business and Management Review, 4 (9), 1-23.

[20] Karia, A. O., Omari, S., Mwanaongoro, S., \& Kimori, Y. (2016). Importance of Training and Development on Performance of Public Water Utilities in Tanzania. African Journal of Education and Human Development, 2 (2), 10-18.

[21] Asfaw, A. M., Argaw, M. D., \& Bayissa, L. (2015). The Impact of Training and Development on Employee Performance and Effectiveness: A Case Study of District Five Administration Office, Bole Sub-City, Addis Ababa, Ethiopia. Journal of Human Resource and Sustainability Studies, 03 (04), 188-202. 
[22] Mwapira, D. (2015). The role of employees' training in organizational Performance: A case study of Tanzania revenue authority (TRA) Offices at Ilala tax region.

[23] Tambwe, A. M. (2015). The Impact of Entrepreneurship Training on Micro and Small Enterprises' (Mses) Performance in Tanzania: The Case of Food Vendors in Ilala District Dar Es Salaam. Business Education Journal, 1 (1), 1-18.

[24] Pallant, J. (2016). SPSS Survival Manual (6th ed.). New York, United States of America: McGraw-Hill. 